Article

\title{
Reuse of Animal Manure: A Case Study on Stakeholders' Perceptions about Pelletized Compost in Northwestern Italy
}

\author{
Niccolò Pampuro, Federica Caffaro (i) and Eugenio Cavallo * (1D \\ Institute for Agricultural and Earth Moving Machines (IMAMOTER), Italian National Research \\ Council (CNR)—Strada delle Cacce, 73, 10135 Torino (TO), Italy; n.pampuro@ima.to.cnr.it (N.P.); \\ f.caffaro@ima.to.cnr.it (F.C.) \\ * Correspondence: e.cavallo@imamoter.cnr.it; Tel.: +39-011-397-7724; Fax: +39-011-348-9218
}

Received: 11 May 2018; Accepted: 14 June 2018; Published: 15 June 2018

\begin{abstract}
The present study aimed at investigating perceptions and preferences about the use and the chemical characteristics of pellets made from composted animal manure in a sample of Italian farmers and agricultural advisors (Piedmont region, Northwestern Italy). The study encompassed two different steps: At first, the participants were administered a questionnaire about their actual use of pellets and preferences about their chemical characteristics. Then, a subgroup participated into a hands-on experience with different pelletized animal manures and some final questions. Concerning the use of pellets made from composted animal manure, even if the participants affirmed to be interested in using organic pellets and declared to own the appropriate equipment needed for their application, the results indicated that pelletized compost utilization had not yet become a common practice for agricultural crops. The obtained results highlighted a lack of knowledge, especially among farmers, about the importance of some chemical properties of this pelletized organic material. The participants, both farmers and advisors, were particularly attracted by the total nitrogen content of organic pelletized fertilizers, probably because the supplying of nutrients, nitrogen particularly, is the function of fertilizers they were interested in the most due to its direct connection with crop production. The hands-on session allowed the participants to better understand the benefits of the principal chemical properties-organic matter and carbon to nitrogen ratio - of pelletized animal manure compost. On the other hand, organic matter content and carbon to nitrogen ratio, more related with biological fertility and biodiversity of soils, are immediately less interesting and, as the hands-on experience pointed out, require more effort to be appreciated by agricultural operators. Targeted information campaigns and training activities may be developed among the agricultural community to make them aware of the importance of increasing soil organic matter content, and the possible use of pelletized composted animal manure. Further studies should be addressed toward gaining more insights into the beneficial effects of the information and training activities for pelletized compost adoption.
\end{abstract}

Keywords: pellet; composting; livestock waste management; operator's attitudes; survey investigation; training

\section{Introduction}

Soil organic matter (SOM) plays a key role in determining the quality, productivity, and ecological functioning of soils [1] affecting, directly or indirectly, chemical, biological, and physical properties of belowground components [2]. More specifically, SOM contributes to the nutrient accumulation and supply capacity of soils, to $\mathrm{pH}$ buffering capacity, and retention of pollutants or toxic elements [3]. Moreover, soil organic matter represents the biggest stock of carbon/energy for soil microorganisms and, 
thus, for the whole soil biota, which are key players in soil functionalities [4]. SOM is also fundamental in determining soil structure and, consequently, in controlling soil erosion, water infiltration, and water holding capacity [5-7].

However, Lal [8] affirmed that, as a consequence of the unprecedented expansion and intensification of agriculture during the 20th century, many soils are characterized by an evident decline in SOM content. In particular, input-intensive agricultural practices, such as the use of mineral fertilizers, frequent soil tillage, narrow crop rotations, and past shifts in land use [9] have led to decreased soil organic carbon (SOC) stocks, biodiversity loss, and pollution of groundwater and air [10]. In this context, the Communication "Towards a Thematic Strategy for Soil Protection" [11], adopted by the European Parliament in April 2002, identified eight main threats to soils similar to some initiatives adopted in other developed countries, such as the US [12]. Declining SOM is considered one of the most serious processes in soil degradation, especially in the Mediterranean countries [13]. In particular, according to Jones et al. [14], the Mediterranean regions of Europe exhibits distinctively smaller values of organic carbon (OC) than those of other regions, with substantial areas showing low $(\leq 2 \%)$, or very low $(\leq 1 \%)$, OC.

As reported by Viaene et al. [15], to sustainably increase SOC, farmers should change their soil management practices, which often rely heavily on the application of mineral fertilizers and intensive soil tillage. With the aim of increasing or maintaining the content of soil organic carbon in soils, two types of C-rich input have been identified, namely the plant residues derived from the biomass grown on-site, and various types of biosolids, including those of livestock origin, such as digestate and compost.

Composting is the most widely used eco-friendly approach toward managing the livestock manure and producing valuable organic products [16-18]. Despite knowledge of the benefits related to composted animal manure's application on soil quality [19,20], soil fertility [21-23], and the environment $[24,25]$, this material was increasingly considered as a waste in the Mediterranean regions of Europe [26]. With reference to Italy, application of composted manure is not a common practice [23]. In this specific geographic area, slurry storage for subsequent land application is the predominant manure management practice, probably due to its simplicity and low cost [23]. However, this technique carries several environmental pollution risks, such as ammonia and greenhouse gas emissions into the atmosphere, nitrate leaching into groundwater, and phosphorous runoff into surface waters $[20,27,28]$.

A promising approach toward increasing the benefits of composted animal manure, as well as to create a potential new market for animal manure-derived fertilizer, is to pelletize it. Pelletizing is a densification process that makes it possible to increase the bulk density of compost from $<500 \mathrm{~kg} \mathrm{~m}^{-3}$ to $>1000 \mathrm{~kg} \mathrm{~m}^{-3}[29,30]$. The low density of organic fertilizers, notably compost, is recognized as the most important obstacle for its adoption for agricultural use [31] because of the associated increased transport, handling, storage, and application costs [32]. Furthermore, Alemi et al. [22] and Romano et al. [33] showed that pelletizing homogenizes and further concentrates manure nutrients, thereby improving its fertilizing and amending actions.

Despite the relevant benefits of compost and the importance of operators' perceptions in the diffusion of sustainable innovations [34], Italian operators' attitudes toward the use and preferences for pellets made from composted animal manure have, until now, been little investigated. In this context, the study conducted by Hou et al. [26] on several European countries, among those Italy, highlighted that the reduction of transport costs and increase in market value of manure represent the top benefits linked to pelletizing animal wastes. Specifically, the study of Hou et al. [26] addressed different stakeholders within the Italian agricultural population (mainly farmers and agricultural advisors); however, the focus of the study was the process of pelletizing rather than the final product, i.e., pelletized compost.

The market potential of compost products depends to a large extent on the analysis of the needs and requirements of the targeted market, and how pelletized compost can best meet those particular needs, by clearly demonstrating its beneficial properties [31]. Needs and potential of the targeted market should be analyzed through personal interviews and/or questionnaires with representatives of potential users of the product [31]. 
Based on this, the present study investigated the perceptions and the preferences about the use and the chemical characteristics of pellets made from composted animal manure. The investigation was carried out in a sample of Italian farmers and agricultural advisors, two categories of stakeholders that, in accordance with the study by Hou et al. [26], have the best expertise in the domain of manure treatment.

The present study encompassed two different steps: At first, the participants were administered a questionnaire about their actual use of pellets and preferences about its characteristics. Then, a subgroup participated into a hands-on experience with different pelletized organic fertilizers with some final questions.

Understanding stakeholders' perceptions could highlight some critical issues and suggest possible solutions in terms of policies, marketing strategies, and/or information campaigns to support and promote the use of pelletized compost. This is particularly relevant for the European, and in particular, the Italian context, since the adoption of pelletized compost is still in its early stages.

\section{Materials and Methods}

\subsection{Participants}

The investigation was carried out in the Piedmont region (Northwestern Italy) where, according to the last Italian National Census of Agriculture (2010), about 70,000 farms are located, representing $4.1 \%$ of all Italian farms [35].

The participants in the present investigation were recruited from among the visitors of the 37th National Exhibition of Agricultural Mechanization (15-18 March 2018) in Savigliano, which is the biggest agricultural machinery exhibition in the Piedmont region, with more than 60,000 visitors. We were aware that recruiting participants during such events may lead to a self-selection bias [36]; however, since the agricultural population is spread across the country with varying working hours, these exhibitions represent the best occasions to gather a large and wide-ranging group of farmers and agricultural advisors together. Therefore, such shows represent a suitable place to perform survey investigations and quantitative data collection $[37,38]$.

\subsection{Instruments}

A paper-and-pencil questionnaire was administered to the participants. The sections and items of the questionnaire were designed based on previous instruments $[26,39,40]$, and by considering the main chemical properties of pellets made from composted animal manure. The questionnaire was pilot-tested with four operators before being used for the present investigation.

Two different versions of the questionnaire were developed, one for the farmers and another one for the advisors. The questionnaire included two sections. In the first one, two dichotomous items assessed the actual use of pelletized compost and the availability of appropriate equipment for its application (i.e., rotating spreader). In addition, interest in the use of pellets was assessed by asking farmers how much they were interested in using pellet organic fertilizers on a 7-point rating scale (from $1=$ not at all to $7=$ very much). The same scale was used to ask advisors how much they thought their clients would be interested in the use of such pellets.

The second section of the questionnaire addressed users' preferences about the most important chemical characteristics of pelletized compost for on-farm application. A 7-point rating scale (from $1=$ not at all to $7=$ very much) was used to assess the perceived importance of moisture content $(\mathrm{MC})$, organic matter $(\mathrm{OM})$, total nitrogen $(\mathrm{TN})$, carbon to nitrogen ratio $(\mathrm{C} / \mathrm{N})$, and humic and fulvic acids (HFA). A standard socio-demographic form closed the questionnaire.

For the hands-on experience, both farmers and advisors were physically presented different types of pelletized animal manure compost, and received information about their main chemical characteristic $(\mathrm{OM}, \mathrm{TN}$, and $\mathrm{C} / \mathrm{N})$ and their importance for agronomical application. Eight different types of pellet with specific chemical properties (Table 1), were shown to the participants. At the end 
of the session, the participants had to select which pellet among the different options best fitted the requirements of their crops, also giving the reason for their choice.

Table 1. Main chemical properties of the eight pellet types included in the hands-on session.

\begin{tabular}{|c|c|c|c|c|c|c|c|c|}
\hline \multirow{2}{*}{ Parameter } & \multicolumn{8}{|c|}{ Pellet ID * } \\
\hline & 1 & 2 & 3 & 4 & 5 & 6 & 7 & 8 \\
\hline $\mathrm{OM}(\%)$ & 15.9 & 38.6 & 47 & 44.1 & 42.5 & 42.5 & 64.6 & 27.5 \\
\hline $\mathrm{TN}(\%)$ & 0.6 & 1.9 & 1.3 & 2.5 & 2.0 & 2.0 & 2.8 & 1.8 \\
\hline $\mathrm{C} / \mathrm{N}$ & 14.6 & 12.1 & 23.1 & 27.3 & 12.5 & 12.2 & 13.6 & 9.1 \\
\hline
\end{tabular}

* 1: Composted pig manure mixed with wheat straw; 2: Composted pig manure mixed with sawdust; 3 : Composted pig manure; 4: Poultry manure; 5: Horse and cattle manure; 6: Horse manure; 7: Horse, poultry, and cattle manure; 8: Horse and cattle manure mixed with vegetable wastes.

\subsection{Procedure}

The questionnaire was handed out to the visitors of the exhibition by trained research assistants. The assistants explained the aims of the study and informed the participants that the questionnaire was anonymous. The questionnaire was in Italian and it took approximately $3-4 \mathrm{~min}$ to be filled in. After that, the participants who agreed to take part in the second step of the study were accompanied to an exhibition stand where they were shown the eight different types of pellet and received an explanation about the chemical properties. This second part of the research took approximately $15 \mathrm{~min}$ to be performed. The participants were not offered any incentive to volunteer.

\subsection{Data Analysis}

Descriptive statistics were calculated for the variables of interest for both the farmers and the agricultural advisors. Comparisons between the perceptions and preferences of the two groups were performed using independent samples $t$-tests and $\chi^{2}$ tests. The analysis was conducted with SPSS software v.24 (IBM Corp.: Armonk, NY, USA).

\section{Results and Discussion}

Forty-four farmers and 38 agricultural advisors took part in the first phase of the study. The main sociodemographic characteristics of the participants are reported in Table 2. Participants' variability in terms of age, gender, and education was a good representation of the Piedmont and Italian agricultural population, as reported in the 2010 Italian Sixth Agricultural Census [41]. Respondents also represent the most relevant agricultural crops in the Piedmont Region [41].

Table 2. Main socio-demographic characteristics of the participants.

\begin{tabular}{cccc}
\hline \multirow{2}{*}{ Variables } & Levels & Farmers & Advisors \\
\cline { 3 - 4 } & & $\mathbf{n}$ & $\mathbf{n}$ \\
\cline { 3 - 4 } Gender & Male & 42 & 37 \\
& Female & 2 & 1 \\
\hline \multirow{3}{*}{ Education } & Primary School & 1 & - \\
& Middle School & 8 & - \\
& Secondary School & 29 & 7 \\
& University & 6 & 31 \\
Farm operation * & Vineyard & 19 & 10 \\
& Horticulture/Gardening & 9 & 16 \\
& Hazelnut & 12 & 10 \\
\hline Age & Cereals & 25 & Mean (Standard Deviation) \\
\hline Work Experience (years) & & 43.57 (12.26) & Mean (Standard Deviation) \\
\hline Farm Size (ha) & & $21.33(11.84)$ & (11.99) \\
\hline No. of Assisted Farms & & 62.86 (54.17) & - \\
\hline
\end{tabular}

* Multiple answers were possible. For agricultural advisors, the data refers to the types of farm operations assisted. 
The analysis showed that age and years of work experience did not significantly differ between farmers and advisors ( $p>0.05$ in both comparisons). With regard to education, a $\chi^{2}$ test pointed out that advisors had a higher level of education compared to farmers $\left(\chi^{2}(3)=8.64, p=0.034\right)$. However, this difference mirrors the more recent statistics about the Italian farming population [41]. Concerning farm size, it should be noticed that our participants represented various types of farm operation, from vineyards to cereals, thus their farms ranged between 3 and 200 ha, as is typical of these operations.

\subsection{Reported Use of Pellettized Animal Manure Compost and Attitudes toward It}

With regard to the actual use of pellets, 36 farmers declared they had the appropriate equipment (i.e., a rotating spreader) for pellet application. However, only 10 farmers out of 44 reported having already used organic fertilizers, in particular pelletized animal manure compost.

Among advisors, 29 out of 38 thought that their clients had the proper equipment (i.e., a rotating spreader) to distribute pellets, and 19 out of 38 reported having suggested their clients use organic fertilizer on their farm, in particular pelletized animal manure compost.

Regarding the interest in the use of pellets made from composted animal manure, the $t$-test did not show any significant differences between farmers and advisors $(t(46)=0.338, p=0.737)$, even though farmers were slightly more interested compared to advisors $\left(\mathrm{M}_{\text {farmer }}=5.60 \mathrm{vs} . \mathrm{M}_{\text {advisor }}=5.44\right)$.

Concerning data on pelletized animal manure compost utilization, even if the participants reported to be interested in using organic pellets and declared to own the appropriate equipment needed for their application, the obtained results indicated that, in the investigated sample, pelletized compost utilization has not yet become a common practice for agricultural crops. This data is in line with the study conducted in Florida by Rahmani et al. [39] focused on compost users' attitudes toward compost application. Pelletized compost availability and quality inconsistencies, such as immature compost, percent of weed seeds, and odor could be the main barriers to using organic pellets. However, several studies [42-44] indicate that increased profitability is an incentive for adopting an innovation. In this context, the application of pelletized animal manure compost as a partial substitute for the mineral fertilizers, could lead to a reduction in production costs, increasing farm profitability [21].

\subsection{Perceived Importance of Chemical Characteristics}

The importance attributed by farmers and advisors to each chemical characteristic of pellets is reported in Figure 1A,B, respectively. As it can be seen, the OM was the most important characteristic for both farmers and advisors.

According to Nyamangara et al. [45], the application of composted organic material is the key for sustainable management of soil organic matter. Several studies have highlighted the beneficial effects of organic amendment for soil quality. Moreover, due to its slow release nutrient capability [46], OM is the main component responsible for the improvement of several soil physical properties, including soil water retention capacity [47,48], saturated hydraulic conductivity [48], compactibility [49], aggregation [50], total porosity and pore size distribution [50], soil crusting [51], and penetration resistance of soil [48].

The $t$-tests showed a significant difference between farmers and advisors regarding the importance attributed to $\mathrm{TN}(t(80)=7.07, p=0.000)$; in particular, the farmers attributed significantly more importance to $\mathrm{TN}$ content compared to advisors $\left(\mathrm{M}_{\mathrm{farmer}}=5.07 \mathrm{vs} . \mathrm{M}_{\mathrm{advisor}}=3.61\right)$. No significant differences emerged regarding the other pelletized organic fertilizer characteristics.

The great importance attributed by farmers to TN content could be due to a lack of knowledge regarding the compost nutrient contents in general [52]. As confirmed by many authors [53-55], compost should be considered as an organic amendment affecting several soil characteristics. These effects can be due to the intrinsic properties of the organic amendment (direct effect), or as an indirect consequence of its beneficial effect on the physical, chemical, and biological properties of the soil [56]. However, the application of composted animal manure alone could not be as effective as for mineral fertilizers because its mineralization time is generally unknown, and therefore, the availability of 
nutrients for the plants is also uncertain [21]. The application of an organic amendment as a substitute for the mineral fertilization is not always appropriate because some crops have high nutrient or punctual needs throughout their cycle, and large quantities of compost would be necessary to satisfy the overall needs of the crop; otherwise, the organic material would not supply sufficient quantities of nutrients at the right moment [45,57]. In this context, Hernandez et al. [54] observed lower yields of tomatoes in soils treated only with compost with respect to yields of the mineral fertilized soils or soils treated with combined organic and inorganic products; this is probably due to nutrient limitation, mainly nitrogen.

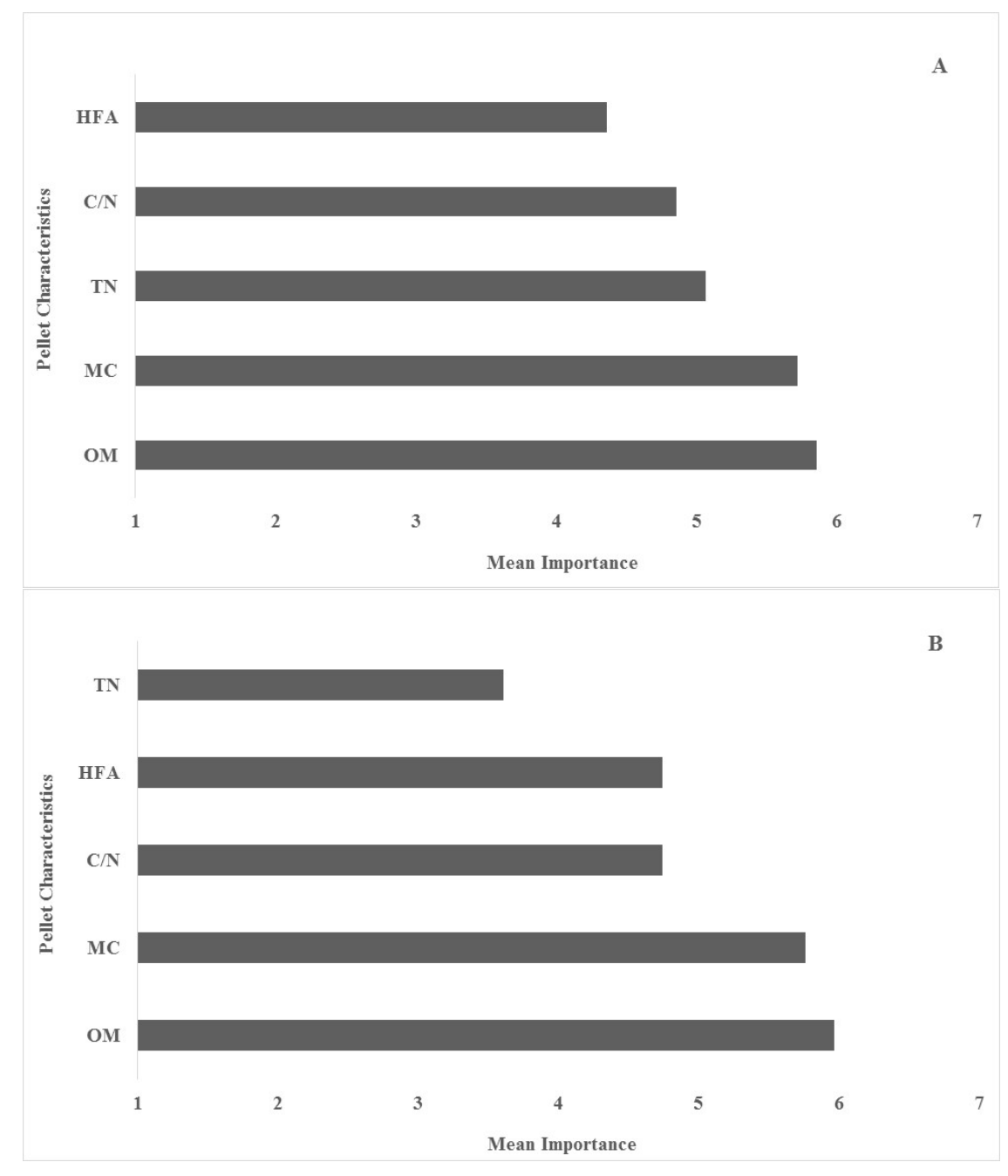

Figure 1. Mean ratings of importance attributed by farmers (A), and by advisors (B), to different chemical characteristics of pellets, namely organic matter (OM), moisture content $(\mathrm{MC})$, total nitrogen $(\mathrm{NT})$, carbon to nitrogen ratio $(\mathrm{C} / \mathrm{N})$, and humic and fulvic acids (HFA).

\subsection{Farmers' and Advisors' Preferences after the Hands-On Experience}

Fourteen farmers and 20 advisors participated in the second phase of the study. As it is reported in Figure 2, advisors and farmers indicated \#7 as the best pellet for agronomic utilization. The reason for this choice was related to the high OM content and the optimal $\mathrm{C} / \mathrm{N}$ ratio value.

As reported by Bernal et al. [16], the $\mathrm{C} / \mathrm{N}$ ratio is one of the most important factors characterizing the quality and maturity of the composted materials. When waste is composted, generally there is a decrease in the $\mathrm{C} / \mathrm{N}$ ratio with time due to losses of $\mathrm{C}$ as $\mathrm{CO}_{2}$, which stabilizes in the range of 
15-20 [58]. Many authors [59-61] reported that values of the $\mathrm{C} / \mathrm{N}$ ratio less than 20 indicates an acceptable maturity, and a ratio of 15 or less is suitable for agronomic use.

On the other hand, pelletized animal manures \#1 and \#4 were considered the least suitable for crops application because of their low value of $\mathrm{OM}$ and high $\mathrm{C} / \mathrm{N}$ ratio, respectively.

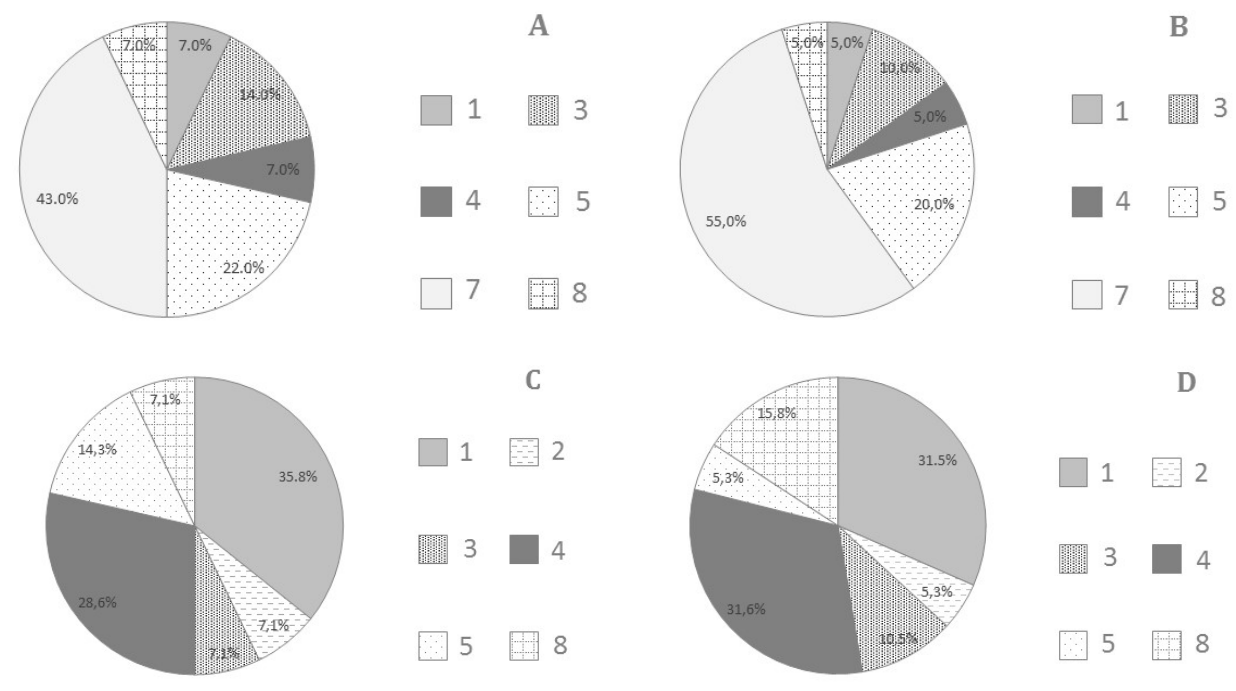

Figure 2. Farmers' and advisors' pellet choice: (A) Farmers' best pellet; (B) Advisors' best pellet; (C) Farmers' worst pellet; (D) Advisors' worst pellet.

\section{Conclusions}

Pelletized compost derived from animal manure typically improves soil quality and fertility; however, its agronomic use is not yet a common practice among the interviewed sample. The minority of advisors and farmers in the present study reported that they used organic pellet fertilizers, even though they owned the appropriate equipment needed for its application.

The obtained results highlighted a lack of knowledge, especially among farmers, about the importance of some chemical properties of this pelletized organic material. The participants, both farmers and advisors, were particularly attracted by the TN content of organic pelletized fertilizers, probably because the supply of nutrients, $\mathrm{N}$ particularly, is the function of fertilizers they were interested in the most due to its direct connection with crop production. The hands-on session allowed the participants to better understand the benefits of the principal chemical properties- $\mathrm{OM}$ and $\mathrm{C} / \mathrm{N}$ ratio- of pelletized animal manure compost. On the other hand, the OM content and $\mathrm{C} / \mathrm{N}$ ratio, which are more related to biological fertility and biodiversity of soils, are immediately less interesting and, as the hands-on experience pointed out, required more effort to be appreciated by agricultural operators. In a future development of the research, the middle- and long-term beneficial effects of such a training activity may be assessed by means of a follow-up questionnaire addressing any changes in farmers' and advisors' views and practices concerning pelletized compost.

Targeted information campaigns and training activities may be developed among the agricultural population to make them aware of the importance of increasing soil organic matter content and the possible use of pelletized composted animal manure. Further studies should be addressed at gaining more insights into the beneficial effects of the information and training activities for pelletized compost adoption.

Author Contributions: N.P., F.C. and E.C. conceived and designed the experiments; N.P. and F.C. administered the questionnaire to the participants and analyzed the data; N.P. and E.C. performed the training session; N.P., F.C. and E.C. wrote the paper.

Funding: This research received no external funding.

Conflicts of Interest: The authors declare no conflict of interest. 


\section{References}

1. Kucerik, J.; Tokarski, D.; Demyan, M.S.; Merbach, I.; Siewert, C. Linking soil organic matter thermal stability with contents of clay, bound water, organic carbon and nitrogen. Geoderma 2018, 316, 38-46. [CrossRef]

2. Nadi, M.; Golchin, A.; Sedaghati, E.; Shafie, S.; Hosseini Fard, S.J.; Fuleky, G. Using nuclear magnetic Resonance $1 \mathrm{H}$ and 13C in soil organic matter covered by forest. J. Water Soil. Sci. 2017, 21, 83-92. [CrossRef]

3. Molina-Herrera, S.; Romanya, J. Synergistic and antagonistic interactions among organic amendments of contrasted stability, nutrient availability and soil organic matter in the regulation of $\mathrm{C}$ mineralization. Eur. J. Soil Biol. 2015, 70, 118-125. [CrossRef]

4. Minasny, B.; McBratney, A.B.; Salvador-Blanes, S. Quantitative models for pedogenesis-A review. Geoderma 2008, 144, 140-157. [CrossRef]

5. Prosdocimi, M.; Jordan, A.; Tarolli, P.; Keesstra, S.; Novara, A.; Cerda, A. The immediate effectiveness of barley straw mulch in reducing soil erodibility and surface runoff generation in Mediterranean vineyards. Sci. Total Environ. 2016, 547, 323-330. [CrossRef] [PubMed]

6. Shi, P.; Schulin, R. Erosion-induced losses of carbon, nitrogen, phosphorous and heavy metals from agricultural soils of contrasting organic matter management. Sci. Total Environ. 2018, 618, 210-218. [CrossRef] [PubMed]

7. Robin, P.; Morel, C.; Vial, F.; Landrain, B.; Toudic, A.; Li, Y.; Akkal-Corfini, N. Effect of three types of exogenous organic carbon on soil organic matter and physical properties of sandy technosol. Sustainability 2018, 10, 1146. [CrossRef]

8. Lal, R. Challenges and opportunities in soil organic matter research. Eur. J. Soil Sci. 2009, 60, 158-169. [CrossRef]

9. Sleutel, S.; De Neve, S.; Singier, B.; Hofman, G. Organic C levels in intensively managed arable soils—Long term regional trends and characterization of fractions. Soil Use Manag. 2006, 22, 188-196. [CrossRef]

10. Kirschenmann, F. Alternative agriculture in an energy and resource depleting future. Renew. Agric. Food Syst. 2010, 25, 85-89. [CrossRef]

11. Commission of the European Communities. Towards a Thematic Strategy for Soil Protection; 16/04/2002 $\operatorname{COM}(2002)$; Communication from the Commission to the Council, the European Parliament, the Economic and Social Committee and the Committee of the Regions; CEC: Bruxelles, Belgium, 2002; p. 35.

12. National Science and Technology Council Committee on Environment, Natural Resources, and Sustainability; Subcommittee on Ecological Sciences; Soil Science Interagency Working Group. The State and Future of U.S. Soils. 2016. Available online: https:/ / obamawhitehouse.archives.gov/sites/default/files/microsites/ostp/ ssiwg_framework_december_2016.pdf (accessed on 11 May 2018).

13. Montanarella, L.; Pennock, D.J.; McKenzie, N.; Badraoui, M.; Chude, V.; Baptista, I.; Mamo, T.; Yemefack, M.; Aulakh, M.S.; Yagi, K.; et al. World's soils are under threat. Soil J. 2016, 2, 79-82. [CrossRef]

14. Jones, R.G.A.; Hiederer, R.; Rusco, E.; Loveland, P.J.; Montanarella, L. The Map of Organic Carbon in Topsoils in Europe; Version 1.2, September 2003: Explanation of Special Publication Ispra 2004vNo.72 (S.P.I.04.72). European Soil Bureau Research Report No 17, EUR 21209 EN 26 pp. and 1 Map in ISO B1 Format; Office for Official Pubblications of the European Communities: Luxembourg, 2003.

15. Viaene, J.; Van Lancker, J.; Vandecasteele, B.; Willekens, K.; Bijttebier, J.; Ruysschaert, G.; De Neve, S.; Reubens, B. Opportunities and barriers to on-farm composting and compost application: A case study from northwestern Europe. Waste Manag. 2016, 48, 181-192. [CrossRef] [PubMed]

16. Bernal, M.P.; Alburquerque, J.A.; Moral, R. Composting of animal manures and chemical criteria for compost maturity assessment. A review. Bioresour. Technol. 2009, 100, 5444-5453. [CrossRef] [PubMed]

17. He, X.; Xi, B.; Wei, Z.; Guo, X.; Li, M.; An, D.; Liu, H. Spectroscopic characterization of water extractable organic matter during composting of municipal solid waste. Chemosphere 2011, 82, 541-548. [CrossRef] [PubMed]

18. Wang, Q.; Awasthi, M.K.; Zhao, J.; Ren, X.; Li, R.; Wang, Z.; Wang, M.; Zhang, Z. Improvement of pig manure compost lignocellulose degradation, organic matter humification and compost quality with medical stone. Bioresour. Technol. 2017, 243, 771-777. [CrossRef] [PubMed]

19. Atiyeh, R.M.; Edwards, C.A.; Subler, S.; Metzger, J.D. Pig manure vermicompost as a component of a horticultural bedding plant medium: effects on physic-chemical properties and plant growth. Bioresour. Technol. 2001, 78, 11-20. [CrossRef] 
20. Zhu, K.; Christel, W.; Bruun, S.; Jensen, L.S. The different effects of applying fresh, composted or charred manure on soil $\mathrm{N}_{2} \mathrm{O}$ emissions. Soil Biol. Biochem. 2014, 74, 61-69. [CrossRef]

21. Gil, M.V.; Carballo, M.T.; Calvo, L.F. Fertilization of maize with compost from cattle manure supplemented with additional mineral nutrients. Waste Manag. 2008, 28, 1432-1440. [CrossRef] [PubMed]

22. Alemi, H.; Kianmehr, M.H.; Borghaee, A.M. Effect of pellet processing of fertilization on slow-release nitrogen in soil. Asian J. Plant Sci. 2010, 9, 74-80.

23. Pampuro, N.; Bertora, C.; Sacco, D.; Dinuccio, E.; Grignani, C.; Balsari, P.; Cavallo, E.; Bernal, M.P. Fertilizer value and greenhouse gas emissions from solid fraction pig slurry compost pellets. J. Agric. Sci. 2017, 155, 1646-1658. [CrossRef]

24. Pampuro, N.; Dinuccio, E.; Balsari, P.; Cavallo, E. Evaluation of two composting strategies for making pig slurry solid fraction suitable for pelletizing. Atmos. Pollut. Res. 2016, 7, 288-293. [CrossRef]

25. Subedi, R.; Taupe, N.; Pelissetti, S.; Petruzzelli, L.; Bertora, C.; Leahy, J.J.; Grignani, C. Greenhouse gas emissions and soil properties following amendment with manure-derived biochars: Influence of pyrolysis temperature and feedstock type. J. Environ. Manag. 2016, 166, 73-83. [CrossRef] [PubMed]

26. Hou, Y.; Velthof, G.L.; Case, S.D.C.; Oelofse, M.; Grignani, C.; Balsari, P.; Zavattaro, L.; Gioelli, F.; Bernal, M.P.; Fangueiro, D.; et al. Stakeholder perceptions of manure treatment technologies in Denmark, Italy, the Netherlands and Spain. J. Clean. Prod. 2018, 172, 1620-1630. [CrossRef]

27. ISTAT-Italian National Institute of Statistics. Preliminary Results of the 6th General Census of Agriculture; ISTAT: Rome, Italy, 2012.

28. Salazar, F.J.; Chadwick, D.; Pain, B.F.; Hatch, D.; Owen, E. Nitrogen budgets for three cropping systems fertilized with cattle manure. Bioresour. Technol. 2005, 96, 235-245. [CrossRef] [PubMed]

29. Vazquez, M.A.; De La Varga, D.; Plana, R.; Soto, M. Integrating liquid fraction of pig manure in the composting process for nutrient recovery and water reuse. J. Clean. Prod. 2015, 104, 80-89. [CrossRef]

30. Pampuro, N.; Facello, A.; Cavallo, E. Pressure and specific energy requirements for densification of compost produced from swine solid fraction. Span. J. Agric. Res. 2013, 11, 678-684. [CrossRef]

31. Eggerth, L.L.; Diaz, L.F.; Chang, M.T.F.; Iseppi, L. Chapter 12 Marketing of composts. Waste Manag. Ser. 2007, 8, 325-355. [CrossRef]

32. Pampuro, N.; Preti, C.; Cavallo, E. Recycling pig slurry solid fraction compost as sound absorber. Sustainability 2018, 10, 277. [CrossRef]

33. Kaliyan, N.; Vance Morey, R. Factors affecting strength and durability of densified biomass products. Biomass Bioenergy. 2009, 33, 337-359. [CrossRef]

34. Romano, E.; Brambilla, M.; Bisaglia, C.; Pampuro, N.; Foppa Pedretti, E.; Cavallo, E. Pelletization of composted swine manure solid fraction with different organic co-formulates: Effect of pellet physical properties on rotating spreader distribution patterns. Int. J. Recycl. Org. Waste Agric. 2014, 3, 101-111. [CrossRef]

35. Cavallo, E.; Ferrari, E.; Bollani, L.; Coccia, M. Attitudes and behaviour of adopters of technological innovations in agricultural tractors: A case study in Italian agricultural system. Agric. Syst. 2014, 130, 44-54. [CrossRef]

36. McBurney, D.H.; White, T.L. Metodologia Della Ricerca in Psicologia; Il Mulino: Bologna, Italy, 2008.

37. Caffaro, F.; Cavallo, E. Comprehension of safety pictograms affixed to agricultural machinery: A survey of users. J. Saf. Res. 2015, 55, 151-158. [CrossRef] [PubMed]

38. Caffaro, F.; Micheletti Cremasco, M.; Roccato, M.; Cavallo, E. It does not occur by chance: a mediation model of the influence of workers' characteristics, work environment factors, and near misses on agricultural machinery-related accidents. Int. J. Occup. Environ. Health 2017, 23, 52-59. [CrossRef] [PubMed]

39. Rahmani, M.; Hodges, A.W.; Kiker, H.C. Compost users'attitudes toward compost application in Florida. Compost Sci. Util. 2004, 12, 55-60. [CrossRef]

40. Appiah-Effah, E.; Nyarko, K.B.; Adum, L.; Antwi, E.O.; Awuah, E. Perception of peri-urban farmers on fecal sludge compost and its utilization: A case study of three peri-urban communities in Ashanti Region of Ghana. Compost Sci. Util. 2015, 23, 267-275. [CrossRef]

41. ISTAT Italian National Institute of Statistics. Human Capital and Social Stratification in Agricultural Italy According to the 6th General Census of Agriculture; ISTAT: Rome, Italy, 2013.

42. Contant, C.K.; Korsching, P.F. Farmers' commitment to continued use of the late spring soil nitrogen test. Am. J. Altern. Agric. 1997, 12, 20-27. [CrossRef] 
43. Fuglie, K.O.; Kascak, C.A. Adoption and diffusion of natural-resource-conserving agricultural technology. Rev. Agrc. Econ. 2001, 23, 386-403. [CrossRef]

44. Nunez, J.; McCann, L. Crop farmers' willingness to use manure. In Proceedings of the American Agricultural Economics Association, Annual Meeting Presented at the American Agricultural Economics Association, Denver, CO, USA, 1-4 August 2004; p. 25.

45. Nyamangara, J.; Bergstrom, L.F.; Piha, M.I.; Giller, K.E. Fertilizer use efficiency and nitrate leaching in a tropical sandy soil. J. Environ. Qual. 2003, 32, 599-606. [CrossRef] [PubMed]

46. Choi, B.; Lim, J.E.; Sung, J.K.; Jeon, W.T.; Lee, S.S.; Oh, S.E.; Yang, J.E.; Ok, Y.S. Effect of rapeseed green manure amendment on soil properties and rice productivity. Commum. Soil Sci. Plant Nutr. 2014, 45, 751-764. [CrossRef]

47. Epstein, E.; Taylor, J.M.; Chaney, R.L. Effects of sewage sludge and sludge compost applied to soil on some soil physical and chemical properties. J. Environ. Qual. 1976, 5, 422-426. [CrossRef]

48. Kumar, S.; Mallik, R.S.; Dahiya, I.S. Influence of different wastes upon water retention transmission and contact characteristics of sandy soil. Aust. J. Soil Res. 1985, 23, 131-136. [CrossRef]

49. Stone, R.J.; Ekwue, E.I. Maximum bulk density achieved during soil compaction as affected by the incorporation of three organic materials. Trans. ASAE 1993, 36, 1713-1719. [CrossRef]

50. Pagliai, M.; Guidi, G.; La Marca, M.; Giacchetti, M.; Lucamante, G. Effects of sewage sludges and composts on soil porosity and aggregation. J. Environ. Qual. 1981, 10, 556-561. [CrossRef]

51. Pagliai, M.; Bisdom, E.B.A.; Ledin, S. Changes in surface structure (crusting) after application of sewage sludge and pig slurry to cultivated agricultural soils in northern Italy. Geoderma 1983, 30, 35-53. [CrossRef]

52. Case, S.D.C.; Oelofse, M.; Hou, Y.; Oenema, O.; Jensen, L.S. Farmer perceptions and use of organic waste products as fertilisers-A survey study of potential benefits and barriers. Agric. Syst. 2017, 151, 84-95. [CrossRef]

53. Janos, P.; Vavrova, J.; Herzogova, L.; Pilarova, V. Effects of inorganic and organic amendments on the mobility (leachability) of heavy metals in contaminated soil: A sequential extraction study. Geoderma 2010, 159, 335-341. [CrossRef]

54. Hernandez, T.; Chocano, C.; Moreno, J.L.; Garcia, C. Towards a more sustainable fertilization: combined use of compost and inorganic fertilization for tomato cultivation. Agric. Ecosyst. Environ. 2014, 196, 178-184. [CrossRef]

55. Idrovo-Novillo, J.; Gavilanes-Teran, I.; Bustamante, M.A.; Paredes, C. Composting as a method to recycle renewable plant resources back to the ornamental plant industry: Agronomic and economic assessment of composts. Process Saf. Environ. Prot. 2017, 116, 388-395. [CrossRef]

56. Tejada, M.; Hernandez, M.T.; Garcia, C. Soil restoration using composted plant residues: Effects on soil properties. Soil Tillage Res. 2009, 102, 109-117. [CrossRef]

57. Bazzoffi, P.; Pellegrini, S.; Rocchini, A.; Morandi, M.; Grasselli, O. The effect of urban refuse compost and different tractor tyres on soil physical properties, soil erosion and maize yield. Soil Tillage Res. 1998, 48, 275-286. [CrossRef]

58. Golueke, C.G. Prinicples of biological resource recovery. Biocycle 1981, 22, 36-40.

59. Mathur, S.P.; Owen, G.; Dinel, H.; Schnitzer, M. Determination of compost biomaturity. Literature review. Biol. Agric. Hotic. 1993, 10, 65-85. [CrossRef]

60. Bernal, M.P.; Paredes, C.; Sanchez-Monedero, M.A.; Cegarra, J. Maturity and stability parameters of compost prepared with a wide range of organic wastes. Bioresour. Technol. 1998, 63, 91-99. [CrossRef]

61. Swarnam, T.P.; Velmurugan, A.; Pandey, S.K.; Dam Roy, S. Enhancing nutrient recovery and compost maturity of coconut husk by vermicomposting technology. Bioresour. Technol. 2016, 207, 76-84. [CrossRef] [PubMed]

(C) 2018 by the authors. Licensee MDPI, Basel, Switzerland. This article is an open access article distributed under the terms and conditions of the Creative Commons Attribution (CC BY) license (http:// creativecommons.org/licenses/by/4.0/). 